\title{
Beyond Content: The Value of Instructor-Student Connections in the Online Classroom
}

\author{
John Paul Steele \\ Grand Canyon University \\ john.steele@gcu.edu \\ Sarah N. Robertson \\ Grand Canyon University \\ sarah.robertson@gcu.edu \\ B. Jean Mandernach \\ Grand Canyon University
}

\begin{abstract}
Research clearly establishes the value of online education to foster students' cognitive understanding of course material. However, engagement in the learning experience requires more than mere acquisition of new knowledge; to be fully engaged in the learning process, students must also connect with their peers and instructor in a meaningful way. The purpose of this study is to examine the value of instructor-personalized audio lectures as means of fostering students' engagement with course content and the online learning experience. Qualitative data on the student experience found that instructor-personalized audio lectures enhanced students' perceptions of value and engagement; quantitative data using a standardized engagement measure revealed no significant differences. Students' qualitative feedback about their online learning experience indicated that instructor-personalized audio lectures fostered greater student-instructor connections and significantly impacted the likelihood of students' engaging with course material. Recognizing the value of student engagement for ongoing satisfaction and retention in online learning programs, findings suggest that the creation of personalized audio lectures provides an efficient and effective means for faculty to positively impact students' online learning experience.
\end{abstract}

Keywords: Personalization, student engagement, audio lectures, teacher presence, connectedness,

\section{Introduction}

Advances in online education have opened up a host of opportunities for the integration of multimedia to enhance students' experiences learning remotely. As technology has improved, so has access to a plethora of open educational resources (OER), publisher supplements and other standardized instructional supplements that can be integrated into an online course. While the research clearly shows the cognitive value of educational multimedia for increasing student learning, the availability of such an array of standardized educational supplements challenges the need for online instructors to create their instructional supplements. Within this context, it is imperative to examine the value of instructor's investing their time and energy to create 
multimedia content. If standardized, instructional supplements produce student learning, engagement and satisfaction outcomes that are equivalent to those found in response to instructorgenerated instructional content, then it can be argued that online faculty would benefit from integrating existing content (i.e., OER, publisher or online) and investing their time in other instructional tasks. However, if there is a unique benefit for students to receive content created by their instructor, then there is value in online faculty's investment of instructional time in the creation of personalized multimedia. The purpose of this study is to examine the value of instructor-generated audio lectures (in comparison to non-personalized, standardized content presentations) for impacting students' engagement with the online learning experience.

\section{Cognitive Power of Personalized Multimedia}

The integration of multimedia supplements in the online classroom provides the opportunity for students to review of course content (Bligh, 2000) and interact in a manner that aligns with their learning preference (Hallet \& Faria, 2006). Research clearly establishes the cognitive value of audio lectures in the online classroom (Spickard, Alrajeh, Cordray, \& Gigante, 2002). Spickard III, Smithers, Cordray, Gigante and Wofford (2004) found that students spent more time on and were more satisfied with an audio lecture versus a text-based comparison; these same students were also noted to have higher post-lecture knowledge scores. Stiffler, Stoten, and Culle, (2011) found that students were able to multi-task while listening to supplementary podcasts and students indicated that they were equally important. Ralph and Olsen (2007) noted the power of the human voice and the advantages it can have for making complex topics more "comprehensible and resonant" (p.272). Williams and Fardon (2007) add that digitally recorded lectures strengthened student comprehension of content. Kaplan-Leiserson supports this with their research finding podcasts to be practical tools for individuals with strong auditory learning preferences as written information may mean little when it is not heard for those learners (2005). Further, the majority of students $(70.4 \%)$ believed audio lectures were useful in supporting their learning and increased teaching presence.

\section{Fosters Further Engagement with Course Material}

Beyond the cognitive value of audio lectures, instructor-generated supplements may provide a means of fostering student engagement with course material. This engagement is essential in the online classroom due to the remote, isolated nature of the learning environment; instructional content and activities that foster students' intrinsic motivation are key to promoting enjoyment, effort, and task persistence (Kaufman \& Dodge, 2009). While the value of student engagement is not unique to online learning, when students are learning in geographic isolation, the role, and importance of engagement becomes much more pronounced.

Student engagement is a key indicator of learning success in the online classroom (Handelsman, Briggs, Sullivan \& Tower, 2005). Despite its importance, engaging students in the online environment hosts a range of challenges due to the asynchronous nature of interactions and the lack of face-to-face interaction (Wang, Shannon, \& Ross, 2013). Most online courses provide instructional material in a written format, but multimedia offers a host of opportunities to present content in a more dynamic, engaging manner. While research (Spickard, Alrajeh, Cordray, \& Gigante, 2002) finds that audio lectures are equivalent to their face-to-face counterparts in promoting student learning, there is minimal information on the value of this type of multimedia

Journal of the Scholarship of Teaching and Learning, Vol. 18, No. 4, December 2018. josotl.indiana.edu 
inclusion on other aspects of the online learning experience, such as interest, satisfaction or engagement.

Engaged students tend to be better learners; critical to this relationship, effective instruction inspires and upholds student engagement (Handelsman et al., 2005). Wang, Shannon, and Ross (2013) theorize that the level of a student's motivation heavily impacts the student's level of course satisfaction. Additionally, higher levels of course satisfaction and technology self-efficacy are also associated with better outcomes (Wang et al., 2013). Incorporating instructor-generated audio lectures may add to students' level of course satisfaction by actively fostering a more personalized instructor-student connection.

\section{Enhances Student-Teacher Relations}

Audio lectures provide an efficient means for instructors to personalize and humanize the online learning experience. Presenting instructional content in a more personalized manner that reveals more of the instructor's personality, thus allowing instructors the opportunity to increase their teaching presence (Garrison, Anderson \& Archer, 2000) and may impact learners' psychosocial needs. Horzum (2011) found students felt more engaged and satisfied with the online learning experience when they felt a connection with their instructor. Moore (1997) discusses transactional distance theory as the imaginary amount of separation between the instructor and students. Substantial transactional distance results in low student engagement as students feel separated and disconnected from the class and/or instructor. When combined with a real physical separation, this disconnect between online students and the classroom is intensified. If the imaginary psychological separation is reduced, students will feel more connected with their instructor and class (Moore, 1997). This desire for connection with the instructor was highlighted in Dzakiria, Kasim, Mohamed, and Christopher's (2013) study in which students pleaded for a sense of connection to the instructor stating "the teacher is always there, but isn't" (p.112). Instructor-generated instructional supplements may be able to create a synergetic connection between the instructor and students reducing perceptions of "distance."

\section{Audio as the most Versatile, Time, and Size Efficient Choice}

Audio lectures (i.e., MP3) provide unique value and opportunity in comparison to their more advanced multimedia counterparts. From a faculty perspective, audio lectures are much less time consuming to create (Copley, 2007), require little technology expertise or specialized hardware/software, and are amenable to transcription programs. From a student perspective, audio lectures increase users' mobility to listen to lectures on the go. This element of convenience allows students flexibility in accessing course materials and enables them to listen to the lectures while driving, completing their daily fitness, or at some other time as one would with an audio book (Fernandez, 2007).

Audio files may be more accessible via the technology and/or Internet bandwidth available to students. Video or multimedia files require increased bandwidth and specialized viewers to access efficiently; these features may not be available to students on the less privileged side of the technological divide. In contrast, audio lectures typically have a much smaller file size and can be stored in a larger array of devices (Cragg, Andresyszyn, \& Humbert, 1999). This flexibility allows students to download audio course material to their iPod, non-Apple music device, phone, and more. Reflecting this value, Bickerdike, Whittle, and Pickering (2014) found a high level of

Journal of the Scholarship of Teaching and Learning, Vol. 18, No. 4, December 2018. josotl.indiana.edu 
student usage (consistently over 50\%) for audio lectures; the key to the utility was students' ability to access the audio files on their mobile devices.

As discussed by Clark and Mayer (2011), content delivered in a conversational, personalized tone promotes increased learning and engagement as it evokes the natural tendency to focus attention on social conversations (Clark \& Mayer, 2011). Thus, meaningful, personalized learning components (i.e., audio lectures) have the potential to mediate the distance barriers inherent in an asynchronous learning environment (Mandernach, 2009). While there are countless ways that instructors can personalize the online classroom (as demonstrated by Kurt, 2011, personalization can be as simple as using a conversational message in place of a more formal message). This study focuses on the use of audio lectures due to their ease of use, mobility, and minimal technical requirements. The purpose of this study is to examine the value of instructorgenerated audio lectures (in comparison to non-personalized, standardized presentations of content) for impacting students' engagement in the online classroom.

\section{Methods}

\section{Participants}

The sample consisted of first-year undergraduate students in an introductory an online course at a university in the southwest. One hundred thirty-eight students enrolled in the course sections utilized in this study; all students were invited to complete the survey at the end of the course. Participants spanned across multiple sections of the same undergraduate course within the Fall 2014 semester. This course is typically the students' third class in their program. Classes were randomly assigned to receive either personalized audio lectures or standardized audio lectures. A total of 82 students completed the final survey. Through data cleaning and screening, three participants' responses were disregarded due to incomplete survey responses. This resulted in a sample of 79 participants, 31 within the experimental group (personalized, instructor generated audio lectures) and 46 within the control group (standardized audio lectures). Response rates per class section, and group is listed in tables 1 and 2 respectively.

Table 1. Personalized sections

\begin{tabular}{llll}
\hline Section & Total students in class & $\begin{array}{l}\text { Number of students } \\
\text { using video lectures }\end{array}$ & Response rate \\
\hline Class \#1 & 11 & 5 & $45 \%$ \\
Class \#2 & 24 & 12 & $50 \%$ \\
Class \#3 & 25 & 14 & $56 \%$ \\
\hline
\end{tabular}

Table 2. Standardized sections

\begin{tabular}{llll}
\hline Section & Total students in class & $\begin{array}{l}\text { Number of students } \\
\text { using video lectures }\end{array}$ & Response rate \\
\hline Class \#1 & 25 & 17 & $68 \%$ \\
Class \#2 & 25 & 13 & $52 \%$ \\
Class \#3 & 28 & 18 & $72 \%$ \\
\hline
\end{tabular}

Journal of the Scholarship of Teaching and Learning, Vol. 18, No. 4, December 2018. josotl.indiana.edu 


\section{Procedures}

The study consisted of a between-groups design where three of the sections of a single introductory course were supplemented with personalized audio lectures made with their instructor's voice. In these three classes, students were informed that it was their instructor's voice. The other three sections supplemented with standardized audio lectures where the students were told the lectures were made by the university; to highlight that these videos were not created by the course instructor, the control videos featured the voice of the opposite gender. To control for consistency in instructional content, the authors of the study (one male and one female) created the two audio lectures; each audio lecture contained identical content. One instructor taught two standardized and two personalized lectures while another instructor taught one personalized and one standardized class with an audio lecture. Both instructors taught the same sections of the same introductory course at the same university. The introductory course remained the same throughout the study although the course sections varied by start date, the week the participants were given the study and instructor (Instructor A or Instructor B).

Both faculty members utilized personalized audio lectures in half of their sections and standardized audio lectures in the other half. The length of the audio lectures ranged from just over five minutes to just over nine minutes depending on the content presented in the written lecture for that week. The lectures are also presented under the course materials in a written format, so the same material was presented in a written format that focused on the same weekly content of the course. Students were notified of the audio lectures in the first week of class in the discussion forum. All audio lectures were uploaded in the discussion forum under the first discussion question as MP3 links during each week of the course. This was consistent across all courses as was the content and conditions. The surveys are included in the Appendix B. Students were informed of the study in the discussion forum and notified that by participating in the study as all results were confidential and participation in the study was not required.

In order to collect appropriate data, the current study used an electronic survey hosted by SurveyMonkey.com. The link to one of the two surveys link variations (varied depending on group) was posted in the discussion forum of the online classroom. Participants were also informed of the survey within the same post in the discussion forum. All data was collected anonymously. Students were invited to listen to the audio lectures using an announcement in the classroom discussion forum, but it was not required as part of the class. There was an audio lecture each week of the seven-week course that mirrored the written lecture.

\section{Materials}

Audio lectures were created using instructor cell phones. Each lecture was pre-scripted. Instructors did not make any edits to the audio files. All were recorded within one to two attempts, taking about 7-12 minutes to record and upload each audio lecture Instructor A utilized the Voice Record Pro application on an Apple phone with the standard Apple headphones. Instructor B used Hi-Q MP3 Voice Recorder for a Samsung, android phone with Beats wireless headphones. It is of importance to note that these audio recordings could have also been created using a tablet or a computer with varying applications.

The survey included demographic questions, questions targeting students' perception of the learning experience and the student course engagement questionnaire (SCEQ; Handelsmann et al., 2005). Handelsmann et al., (2005) had previously given this study to 266 undergraduate

Journal of the Scholarship of Teaching and Learning, Vol. 18, No. 4, December 2018. josotl.indiana.edu 
students and found their sample to be representative of the student body. Students responded to each item using a five-point Likert-type rating scale ranging from (1) not at all characteristic of me to (5) very characteristic of me with a possible score of 25-125 is displayed in Appendix A. Higher scores indicate a higher level of engagement in the course. The purpose of using the student engagement portion of the survey was to see which students were engaged in the classroom and whether or not it impacted their perceptions of the usefulness of the audio lectures. The student engagement questionnaire consisted of 27 behaviors and attitudes found to be indicative of engagement. Handelsmann et al., (2005) determined that their student engagement questionnaire was a valid, reliable and multi-dimensional measure of college student course engagement.

Questions on the educational experience measured student's perceptions of the audio lectures and the personalization aspect. Students were asked a series of 10 questions using a 5 point standard Likert scale. It stated "Rate your agreement with the following statements:" (1) strongly disagree to (5) strongly agree with a possible score of 10-50. Upon completing these 10 question student were asked the open-ended question: "How beneficial was the auditory lecture to you personally? Please explain your answer." The purpose of the open-ended question was to harness the student perceptions about what was most beneficial about the audio lectures. The standardized participants were asked one additional Likert scale statement using the same scale as above 1-5 (1) strongly disagree to (5) strongly agree. The statement was "It would be beneficial to me personally if the lecture were my instructor's voice".

\section{Results}

Qualitative open response results were collected and coded. Tables 3 and 4 display open response results to question; "How beneficial was the auditory lecture to you personally? Please explain your answer. Results were coded with themes that emerged while compiling results: Useful and added sense of connection with the class/instructor, Useful, Neutral, and Not Useful. Examples are included with each theme as well as the percentage of students coded to the corresponding category (see Table 3).

Table 3. Personalized audio lecture: How beneficial was the auditory lecture to you personally? Please explain your answer

\begin{tabular}{|c|c|c|}
\hline Themes & Examples & Theme $\%$ \\
\hline $\begin{array}{l}\text { Useful and added sense of } \\
\text { connection with the class/instructor }\end{array}$ & $\begin{array}{l}\text { "They made me feel more } \\
\text { connected to the class. Auditory } \\
\text { lectures made the course more } \\
\text { personal." }\end{array}$ & 35.48 \\
\hline Useful & $\begin{array}{l}\text { "The audio lecture helped to } \\
\text { expand and support the material I } \\
\text { read for the lesson. I feel it added } \\
\text { to what I am learning." }\end{array}$ & 48.39 \\
\hline Neutral & $\begin{array}{l}\text { "I only listened to part of one. I am } \\
\text { a visual and hands-on learner so } \\
\text { listening to the audio lecture } \\
\text { would not benefit me. Not saying } \\
\text { that they were not good lectures, }\end{array}$ & 6.45 \\
\hline
\end{tabular}

Journal of the Scholarship of Teaching and Learning, Vol. 18, No. 4, December 2018. josotl.indiana.edu 
Not Useful

but that it is hard for me to learn that way."

"The particular lectures that I

9.68 listened to just seemed to be audio versions of the online version, they didn't seem to add any real value to my progress in the course."

Table 4. Standardized audio lecture: How beneficial was the auditory lecture to you personally? Please explain your answer

\begin{tabular}{|c|c|c|}
\hline Themes & Examples & Theme $\%$ \\
\hline $\begin{array}{l}\text { Useful and added sense of } \\
\text { connection with the class/instructor }\end{array}$ & $\begin{array}{l}\text { "The auditory lectures helped me } \\
\text { understand the topic of the week, } \\
\text { gave me a little break to my eyes } \\
\text { that were getting tired from all the } \\
\text { reading. Also, by hearing the voice } \\
\text { of the instructor, I felt more } \\
\text { connected to the classroom and } \\
\text { instructor." }\end{array}$ & 10.64 \\
\hline Useful & $\begin{array}{l}\text { "The auditory lecture was very } \\
\text { beneficial to me because it allowed } \\
\text { me to take better notes. I was able } \\
\text { to sit back and listen, with hands } \\
\text { free ready to take notes." }\end{array}$ & 85.11 \\
\hline Neutral & $\begin{array}{l}\text { "I am more of a reader and a note } \\
\text { taker. After listening to the audio } \\
\text { lecture, I was pleased to verify I } \\
\text { took good notes when originally } \\
\text { reading the material." }\end{array}$ & 4.26 \\
\hline Not Useful & No examples & 0 \\
\hline
\end{tabular}

Students who listened to the standardized lecture used the standard five point Likert scale to rate the one differentiated statement: "It would be beneficial to me personally if the lecture was my instructor's voice". The results are displayed below in Table 5.

Table 5. Standardized audio lectures: Survey response: It would be beneficial to me personally if the lecture was my instructor's voice

\begin{tabular}{lll}
\hline Themes & Number of responses & Theme $\%$ \\
\hline Strongly Disagree & 1 & 2.08 \\
Disagree & 4 & 8.33
\end{tabular}

Journal of the Scholarship of Teaching and Learning, Vol. 18, No. 4, December 2018.

josotl.indiana.edu 


$\begin{array}{lll}\text { Neutral } & 18 & 37.5 \\ \text { Agree } & 10 & 20.83 \\ \text { Strongly Agree } & 15 & 31.25\end{array}$

Additionally, qualitative results indicate that students perceived personalized audio lectures as not only useful but aided in helping them feel connected to the instructor and/or classroom with a rate of $35.48 \%$ in comparison to their standardized counterparts at $10.64 \%$. Furthermore, students provided with standardized audio lectures perceived that it would be beneficial to them if the audio lecture had been in their own instructor's voice at a rate of $31.25 \%$ for those who strongly agreed and $20.83 \%$ for those who agreed. This equates to a little over half $(52.08 \%)$ of the students claiming a perception of preference for personalized audio lectures. Thus, the students surveyed preferred the personalized audio lectures and found them useful.

A between-groups analysis of variance on the quantitative data revealed no significant differences in student engagement $[F(1,77)=.004, p=.949]$ or perceptions of the usefulness of the audio lectures $[F(1,77)=2.408, p=.125]$ as a learning supplement when comparing students listening to personalized or standardized audio lectures. Similarly, there were no significant differences in students' self-reported level of overall engagement in the course $[F(1,77)=1.184$, $p=.280]$ or engagement in this course compared to other current courses $[F(1,77)=.418, p=$ $.520]$. There was a significant difference in the rate of listening to the audio lectures $[F(1,77)=$ $30.104, p<.001]$ with students in the standardized lecture group listening to 2.38 lectures compared to 3.97 in the personalized condition. The means, and standard deviations for all measures are located in Table 6.

Table 6. Means and standard deviations for engagement and perceptions of learning

\begin{tabular}{lllll}
\hline & & N & Mean & Std. Deviation \\
& & & & \\
\hline \multirow{3}{*}{ Student Course Engagement Questionnaire } & Standardized & 48 & 84.8708 & 14.84306 \\
& Personalized & 31 & 84.6429 & 16.12977 \\
& Total & 79 & 84.7814 & 15.25885 \\
Student Perceptions of Usefulness of Audio & Standardized & 48 & 85.7083 & 11.90022 \\
Lectures & Personalized & 31 & 80.4803 & 18.08156 \\
& Total & 79 & 83.6568 & 14.75397 \\
Student Perceptions of Overall Engagement & Standardized & 48 & 4.0208 & .88701 \\
in Course & Personalized & 31 & 4.2581 & 1.03175 \\
& Total & 79 & 4.1139 & .94716 \\
Student Perception of Engagement in Course & Standardized & 48 & 4.1458 & 1.01036 \\
Compared to Other Current Courses & Personalized & 31 & 4.2903 & .90161 \\
& Total & 79 & 4.2025 & .96582 \\
Number of Audio Lectures Listened To & Standardized & 48 & 2.3750 & 1.23124 \\
& Personalized & 31 & 3.9677 & 1.30343 \\
\hline
\end{tabular}

Journal of the Scholarship of Teaching and Learning, Vol. 18, No. 4, December 2018. josotl.indiana.edu 
The review of the literature on engagement and personalization lead to the further inquiry of teacher presence and student "connectedness" to the class. Within the engagement survey, three questions linked to teacher presence and student connectedness were asked. Table 7 displays those specific questions and their particular data results surrounding rates of responses in which students "agreed" or "strongly agreed."

Table 7. Teacher presence/connectedness questions asked within engagement survey and "agreed" or "strongly agree" results

\begin{tabular}{|c|c|c|c|c|}
\hline $\begin{array}{l}\text { Type of } \\
\text { Audio } \\
\text { Lecture }\end{array}$ & Survey Question & $\begin{array}{l}\text { Number } \\
\text { of total } \\
\text { responses }\end{array}$ & $\begin{array}{l}\text { Number of } \\
\text { "agree" and } \\
\text { "strongly } \\
\text { agree } \\
\text { responses" }\end{array}$ & Theme $\%$ \\
\hline Standardized & $\begin{array}{l}\text { The audio lecture made the online course } \\
\text { seem more personal. }\end{array}$ & 46 & 28 & 60.87 \\
\hline Personalized & $\begin{array}{l}\text { The audio lecture made the online course } \\
\text { seem more personal. }\end{array}$ & 29 & 24 & 61.54 \\
\hline Standardized & $\begin{array}{l}\text { The audio lecture made me feel more } \\
\text { connected to the instructor }\end{array}$ & 46 & 36 & 78.26 \\
\hline Personalized & $\begin{array}{l}\text { The audio lecture made me feel more } \\
\text { connected to the instructor }\end{array}$ & 31 & 26 & 83.87 \\
\hline Standardized & $\begin{array}{l}\text { The audio lecture made me feel more } \\
\text { connected to the classroom }\end{array}$ & 46 & 37 & 80.43 \\
\hline Personalized & $\begin{array}{l}\text { The audio lecture made me feel more } \\
\text { connected to the classroom }\end{array}$ & 31 & 22 & 83.87 \\
\hline
\end{tabular}

\section{Discussion}

While no significant quantitative difference in students' experience was detected, qualitative data indicated higher satisfaction, connection, and engagement by students listening to personalized audio lectures. The findings echo Mandernach's (2009) study in the lack of alignment between quantitative findings and qualitative feedback regarding the usefulness and impact of personalizing multimedia in the online classroom. This discrepancy may indicate that personalization of classroom materials promotes engagement in a manner that is not aligned with existing, standardized measures of engagement.

A significant difference was found in the number of audio lectures listened to by each group which reflected a preference for instructor-generated content; students provided with personalized audio lectures averaged listening to twice as many audio lectures each than students provided with standardized audio lectures. When seeking strategies to convey content in a manner which students are willing to interact with, instructors generating personalized supplemental resources may gain more student attention with those developed materials then instructors utilizing generic materials from the Internet or textbook publishers. Within the previously mentioned Dzakiria et al., (2013) study, students pleaded for as much teacher presence in the classroom as possible. The findings of this study reflect this preference as students were more likely to engage with instructor-generated content compared to equivalent standardized instructional materials. 
While the present sample size was limited, the clear preference for instructor-generated content as revealed by students' open-ended responses provides support for the value of instructors devoting time to create their own instructional supplements (rather than relying exclusively on OER, publisher or standardized content materials). Future research should extend the investigation to address potential differences as a function of course level, discipline, and instructional style. In addition, ongoing research is necessary to understand the scope and limits of personalization; specifically, data is needed to guide instructors on the amount, frequency and type of instructorgenerated content that is most useful to online learners. Additional research may find it worthwhile to investigate whether the increased engagement of audio lectures increased retention rates between courses. Although this study clearly supports that students preferred to interact with instructor-generated audio lectures, it does not explore the ideal balance between instructorgenerated and standardized (e.g., OER or publisher) content within a dynamic online classroom.

It is important to note that the current investigation focused exclusively on audio lectures (as opposed to video or other forms of multimedia) due to the practical advantages provided by this mode of delivery. Compared to more advanced multimedia, audio lectures require less time to create, demand less technology expertise, require less specialized software, utilize less bandwidth, and are more mobile. While these practical advantages are noteworthy, one should not integrate pedagogical strategies simply because they are "easier;" rather, instructional strategies should be selected due to their impact on the learning experience. In this case, audio lectures, despite being an "easy" instructional supplement, created a more engaging connection between online students and their instructor. One could argue (rightfully so) that audio lectures are one of the least personalized forms of instruction (when compared to the audio-visual combination available via video, or the audio-visual-content combination available via a screencast or interactive multimedia). Yet, even when using the most basic form of personalization, the current study found a clear student preference for instructor-generated content. Future research should examine how increasing the level of personalization (audio, audio-visual, or audio-visual-content) may further foster engagement in the online classroom.

Many faculty teaching online cite lack of time as a primary concern for their teaching (Dobbins, 2011; Mueller, Mandernach, \& Sanderson, 2013). Audio lectures provide an efficient, low-investment opportunity for faculty to create a more personalized online learning experience in a manner that is amenable to their busy schedules. The following suggestions provide possible instructional strategies for integrating audio lectures into the online classroom:

- One way to increase teaching presence is through a first exercise, much like that of an "ice breaker." Audio supplements may be integrated at the onset of an online class to establish rapport between the instructor and remote learners. This type of activity allows the instructor to build the confidence with the students by demonstrating that the instructor is approachable, supportive, available and engaged in the student's learning (Kamlaskar \& Killedar, 2015).

- Audio lectures may be utilized as announcements to summarize weekly activities and expectations. This affords students the chance to ask any questions they may have and allows the instructor to set clear expectations. Students value this type of interaction with the instructor (Kamlasker \& Killedar, 2015); audio lecture provides a means of promoting interaction in a more personalized manner.

- Offer audio supplements as an alternative mode for understanding the text-based content provided in the course. Brown et al., (2009) found that podcasting enhanced

Journal of the Scholarship of Teaching and Learning, Vol. 18, No. 4, December 2018. josotl.indiana.edu 
course participation by affording greater opportunities for students with audio or visual learning preferences.

- Audio lectures can be used as a means of providing an on-the-go option for listening to a course lecture. Stiffler, Stoten, and Culle, (2011) found that students were able to multi-task while listening to supplementary podcasts and found podcasts a valuable aspect of their learning experience. Murray et al., (2012) determined that students are often limited due to time constraints in the online environment. Many of today's younger students who are also known as digital natives desire the immediacy for content that derives from audio lectures. For instance, digital natives have always had information at their fingertips while being exposed to free content through digital media such Youtube (Evering \& Moorman, 2012). Thus, they are used to having access to information such as classroom content at the tip of their fingers through their smartphones, tablets, or tablets.

- Audio supplements may be utilized as a component of feedback to students' assignments. Not only does the novelty of including audio feedback increase the likelihood of students' attending to the feedback, but the personalized nature of the interaction may prompt greater attention to corrective strategies (Leibold \& Schwarz, 2015).

- Audio recordings may be used as a way to vary the means of communication within the discussion forum. An instructor could respond to a student's discussion post with an audio response. This could further develop a sense of connection between instructor and student/class as well as help students practice interpreting and then responding to both written and verbal discussion (Cheng, Krumwiede, \& Sheu, 2009).

- At times, responses to students within the individual forum may benefit from a verbal (audio) response rather than a written reply. This could be especially meaningful to students if the response was a condolences or kudos. Furthermore, an audio response may help to clear up any possible "tone" confusion that might be generated from an otherwise misinterpreted written response. Additionally, this could prove as a time saver for faculty as they could record their response walking between classes or driving between locations (Wei, Chen, \& Wang, 2007).

Within the context of this study, it is worth noting that audio lectures provided a key opportunity, not only for personalization but for students to have more control over their online learning experience. Lister (2014) analyzed 17 different studies and found that students preferred to have a choice in how they wish to engage themselves with the course content. Being able to decide how they want to receive the presentation of content was included as the types of choices students prefer to have. By providing the lectures in multiple presentation formats (written or audio) students were given a choice in how they receive the content. This allows students another learning format option and affords a break from reading. In addition, it creates the opportunity for students to take notes while listening to the lecture. And allows students to learn when and where they prefer... even on-the-go. One of the greatest benefits of audio supplements is that students can download the audio lectures in an MP3 format and listen to them on-the-go without having to be in front of their computer. Murray et al., (2012) determined that students were often limited due to time constraints in the online environment. These findings were echoed by Kuo et al., (2014) in which students reported higher levels of course satisfaction and were more likely to use supplemental technology-based resources in an online setting when the tools were easy to use and 
convenient. Providing students the option to create their own preferred learning environment (one in which there are text-based, audio and video options) may be the key to fostering connection, engagement, satisfaction and retention in the online classroom.

\section{Appendix}

\section{Appendix 1. Student Course Engagement Questionnaire}

Rate the extent to which the following behaviors, thoughts, and feelings describe you in this course.

1. Making sure to study on a regular basis

$\begin{array}{llllll}1 & 2 & 3 & 4 & 5 & \text { N/A } \\ \begin{array}{l}\text { Not at all } \\ \text { characteristic } \\ \text { of me }\end{array} & & & \begin{array}{l}\text { Very } \\ \text { characteristic } \\ \text { of me }\end{array} & \begin{array}{l}\text { Not } \\ \text { Applicable }\end{array}\end{array}$

2. Putting forth effort

$\begin{array}{llllll}1 & 2 & 3 & 4 & 5 & \text { N/A } \\ \begin{array}{l}\text { Not at all } \\ \text { characteristic }\end{array} & & & \begin{array}{l}\text { Very } \\ \text { characteristic } \\ \text { of me }\end{array} & \begin{array}{l}\text { Not } \\ \text { Applicable }\end{array}\end{array}$

3. Doing all the homework problems

$\begin{array}{llllll}1 & 2 & 3 & 4 & 5 & \text { N/A } \\ \begin{array}{l}\text { Not at all } \\ \text { characteristic } \\ \text { of me }\end{array} & & & \begin{array}{l}\text { Very } \\ \text { characteristic } \\ \text { of me }\end{array} & \begin{array}{l}\text { Not } \\ \text { Applicable }\end{array}\end{array}$

4. Staying up on the readings.

$\begin{array}{llllll}1 & 3 & 4 & 5 & \text { N/A } \\ \begin{array}{l}\text { Not at all } \\ \text { characteristic }\end{array} & & & \begin{array}{l}\text { Very } \\ \text { characteristic } \\ \text { of me }\end{array} & \begin{array}{l}\text { Not } \\ \text { Applicable }\end{array}\end{array}$

5. Regularly looking over class notes to make sure I understand the material

$\begin{array}{llllll}1 & 2 & 3 & 4 & 5 & \text { N/A } \\ \begin{array}{l}\text { Not at all } \\ \text { characteristic } \\ \text { of me }\end{array} & & & \begin{array}{l}\text { Very } \\ \text { characteristic } \\ \text { of me }\end{array} & \begin{array}{l}\text { Not } \\ \text { Applicable }\end{array}\end{array}$

6. Being organized 
Steele, Robertson and Mandernach

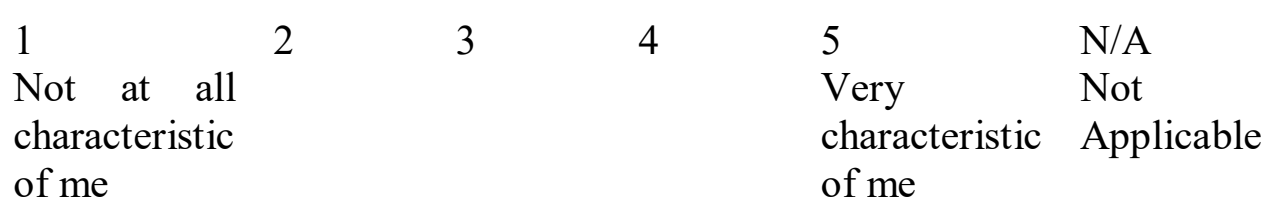

7. Taking good notes

$\begin{array}{llllll}1 & 3 & 4 & 5 & \text { N/A } \\ \begin{array}{l}\text { Not at all } \\ \text { characteristic } \\ \text { of me }\end{array} & & & \begin{array}{l}\text { Very } \\ \text { characteristic } \\ \text { of me }\end{array} & \begin{array}{l}\text { Apt } \\ \text { Applicable }\end{array}\end{array}$

8. Paying careful attention to online resources

$\begin{array}{llllll}1 & 3 & 4 & 5 & \text { N/A } \\ \begin{array}{l}\text { Not at all } \\ \text { characteristic } \\ \text { of me }\end{array} & & & \begin{array}{l}\text { Very } \\ \text { characteristic } \\ \text { of me }\end{array} & \begin{array}{l}\text { Apt } \\ \text { Applicable }\end{array}\end{array}$

9. Regularly logging in to the online classroom

$\begin{array}{llllll}1 & 3 & 4 & 5 & \text { N/A } \\ \begin{array}{l}\text { Not at all } \\ \text { characteristic } \\ \text { of me }\end{array} & & & \begin{array}{l}\text { Very } \\ \text { characteristic } \\ \text { of me }\end{array} & \begin{array}{l}\text { Not } \\ \text { Applicable }\end{array} \\ \end{array}$

10. Finding ways to make the course material relevant to my life

$\begin{array}{llllll}1 & 3 & 4 & 5 & \text { N/A } \\ \begin{array}{l}\text { Not at all } \\ \text { characteristic } \\ \text { of me }\end{array} & & & \begin{array}{l}\text { Very } \\ \text { characteristic } \\ \text { of me }\end{array} & \begin{array}{l}\text { Not } \\ \text { Applicable }\end{array}\end{array}$

11. Applying course material to my life

$\begin{array}{llllll}1 & 3 & 4 & 5 & \text { N/A } \\ \begin{array}{l}\text { Not at all } \\ \text { characteristic } \\ \text { of me }\end{array} & & & \begin{array}{l}\text { Very } \\ \text { characteristic } \\ \text { of me }\end{array} & \begin{array}{l}\text { Apt } \\ \text { Applicable }\end{array}\end{array}$

12. Finding ways to make the course interesting me

$\begin{array}{llllll}1 & 3 & 4 & 5 & \text { N/A } \\ \begin{array}{l}\text { Not at all } \\ \text { characteristic } \\ \text { of me }\end{array} & & & \begin{array}{l}\text { Very } \\ \text { characteristic } \\ \text { of me }\end{array} & \begin{array}{l}\text { Not } \\ \text { Applicable }\end{array} \\ & & & & \text { of }\end{array}$


13. Thinking about the course when I am not logged in to the online classroom

$\begin{array}{llllll}1 & 2 & 3 & 4 & 5 & \text { N/A } \\ \begin{array}{l}\text { Not at all } \\ \text { characteristic }\end{array} & & & \begin{array}{l}\text { Very } \\ \text { characteristic } \\ \text { of me }\end{array} & \begin{array}{l}\text { Not } \\ \text { Applicable }\end{array}\end{array}$

14. Really desiring to learn the material

$\begin{array}{llllll}1 & 2 & 3 & 4 & 5 & \text { N/A } \\ \begin{array}{l}\text { Not at all } \\ \text { characteristic } \\ \text { of me }\end{array} & & & \begin{array}{l}\text { Very } \\ \text { characteristic } \\ \text { of me }\end{array} & \begin{array}{l}\text { Not } \\ \text { Applicable }\end{array}\end{array}$

15. Raising new questions or issues in the online discussions

$\begin{array}{llllll}1 & 2 & 3 & 4 & 5 & \text { N/A } \\ \begin{array}{l}\text { Not at all } \\ \text { characteristic } \\ \text { of me }\end{array} & & & \begin{array}{l}\text { Very } \\ \text { characteristic } \\ \text { of me }\end{array} & \begin{array}{l}\text { Not } \\ \text { Applicable }\end{array}\end{array}$

16. Asking questions when I don't understand the instructor

$\begin{array}{llllll}1 & 3 & 4 & 5 & \text { N/A } \\ \begin{array}{l}\text { Not at all } \\ \text { characteristic } \\ \text { of me }\end{array} & & & \begin{array}{l}\text { Very } \\ \text { characteristic } \\ \text { of me }\end{array} & \begin{array}{l}\text { Not } \\ \text { Applicable }\end{array}\end{array}$

17. Having fun with the online class

$\begin{array}{llllll}1 & 2 & 3 & 4 & 5 & \text { N/A } \\ \begin{array}{l}\text { Not at all } \\ \text { characteristic } \\ \text { of me }\end{array} & & & \begin{array}{l}\text { Very } \\ \text { characteristic } \\ \text { of me }\end{array} & \begin{array}{l}\text { Not Applicable } \\ \text { Apre }\end{array}\end{array}$

18. Participating actively in online discussions

$\begin{array}{llllll}1 & 3 & 4 & 5 & \text { N/A } \\ \begin{array}{l}\text { Not at all } \\ \text { characteristic }\end{array} & & & \begin{array}{l}\text { Very } \\ \text { characteristic } \\ \text { of me }\end{array} & \begin{array}{l}\text { Not } \\ \text { Applicable }\end{array}\end{array}$

19. Emailing the professor to review assignments or tests or to ask questions

$\begin{array}{llllll}1 & 2 & 3 & 4 & 5 & \text { N/A }\end{array}$

Journal of the Scholarship of Teaching and Learning, Vol. 18, No. 4, December 2018. josotl.indiana.edu 
Not at all

characteristic

of me

20. Helping fellow students
Very

characteristic Applicable

of me
Not

Applicable

$\begin{array}{llllll}1 & 3 & 4 & 5 & \text { N/A } \\ \begin{array}{l}\text { Not at all } \\ \text { characteristic }\end{array} & & & \begin{array}{l}\text { Very } \\ \text { characteristic } \\ \text { of me }\end{array} & & \begin{array}{l}\text { Not } \\ \text { ofplicable }\end{array}\end{array}$

21. Getting a good grade

$\begin{array}{llllll}1 & 3 & 4 & 5 & \text { N/A } \\ \begin{array}{l}\text { Not at all } \\ \text { characteristic }\end{array} & & & \begin{array}{l}\text { Very } \\ \text { characteristic } \\ \text { of me }\end{array} & \begin{array}{l}\text { Not } \\ \text { Applicable }\end{array}\end{array}$

22. Doing well on the tests

$\begin{array}{llllll}1 & 2 & 3 & 4 & 5 & \text { N/A } \\ \begin{array}{l}\text { Not at all } \\ \text { characteristic } \\ \text { of me }\end{array} & & & \begin{array}{l}\text { Very } \\ \text { characteristic } \\ \text { of me }\end{array} & \begin{array}{l}\text { Not } \\ \text { Applicable }\end{array}\end{array}$

23. Being confident that I can learn and do well in the class

$\begin{array}{llllll}1 & 2 & 3 & 4 & 5 & \text { N/A } \\ \begin{array}{l}\text { Not at all } \\ \text { characteristic }\end{array} & & & \begin{array}{l}\text { Very } \\ \text { characteristic } \\ \text { of me }\end{array} & \begin{array}{l}\text { Not } \\ \text { Applicable }\end{array}\end{array}$

24. Contacting the professor when I have a question

$\begin{array}{llllll}1 & 2 & 3 & 4 & 5 & \text { N/A } \\ \begin{array}{l}\text { Not at all } \\ \text { characteristic }\end{array} & & & \begin{array}{l}\text { Very } \\ \text { characteristic } \\ \text { of me }\end{array} & \begin{array}{l}\text { Not } \\ \text { Applicable }\end{array}\end{array}$

25. Figuring out what's expected of me in this class

$\begin{array}{llllll}1 & 2 & 3 & 4 & 5 & \text { N/A } \\ \begin{array}{l}\text { Not at all } \\ \text { characteristic } \\ \text { of me }\end{array} & & & \begin{array}{l}\text { Very } \\ \text { characteristic } \\ \text { of me }\end{array} & \begin{array}{l}\text { Not } \\ \text { Applicable }\end{array}\end{array}$


26. How engaged are you in this class?

$\begin{array}{llllll}1 & 2 & 3 & 4 & 5 & \text { N/A } \\ \text { Not at } & & & & \begin{array}{l}\text { Extremely } \\ \text { engaged }\end{array} & \text { Applicable } \\ \text { all } & & & & & \end{array}$

27. How engaged are you in this class, compared to other courses you're taking this semester?

$\begin{array}{llllll}1 & 2 & 3 & 4 & 5 & \text { N/A } \\ \text { Not at } & & & & \begin{array}{l}\text { Extremely } \\ \text { engaged }\end{array} & \text { Applicable } \\ \text { all } & & & & & \end{array}$

\section{Appendix B. Additional Audio Lecture Survey Questions}

Did you listen to the audio lectures provided in this course?
- Yes
- No
- Some

Approximately how many of the audio lectures did you listen to?

Rate your agreement with the following statements:

\begin{tabular}{|l|l|l|l|l|l|l|}
\hline & $\begin{array}{l}\text { Strongly } \\
\text { disagree } \\
1\end{array}$ & Disagree & Neutral & Agree & $\begin{array}{l}\text { Strongly } \\
\text { Agree } \\
5\end{array}$ & $\begin{array}{l}\text { Not } \\
\text { Applicable } \\
0\end{array}$ \\
\hline $\begin{array}{l}\text { The audio lecture helped me to } \\
\text { better understand the course } \\
\text { material. }\end{array}$ & & & 3 & 4 & & \\
\hline $\begin{array}{l}\text { I found the audio lecture } \\
\text { interesting. }\end{array}$ & & & & & & \\
\hline $\begin{array}{l}\text { The audio lecture made the } \\
\text { online course seem more } \\
\text { personal. }\end{array}$ & & & & & & \\
\hline $\begin{array}{l}\text { The audio lecture helped me to } \\
\text { personally connect with my } \\
\text { online instructor. }\end{array}$ & & & & & & \\
\hline $\begin{array}{l}\text { The audio lecture was a good } \\
\text { way for my instructor to share } \\
\text { his/her knowledge of course } \\
\text { topics. }\end{array}$ & & & & & & \\
\hline $\begin{array}{l}\text { The audio lecture was an } \\
\text { important component of my }\end{array}$ & & & & & & \\
\hline
\end{tabular}

Journal of the Scholarship of Teaching and Learning, Vol. 18, No. 4, December 2018. josotl.indiana.edu 


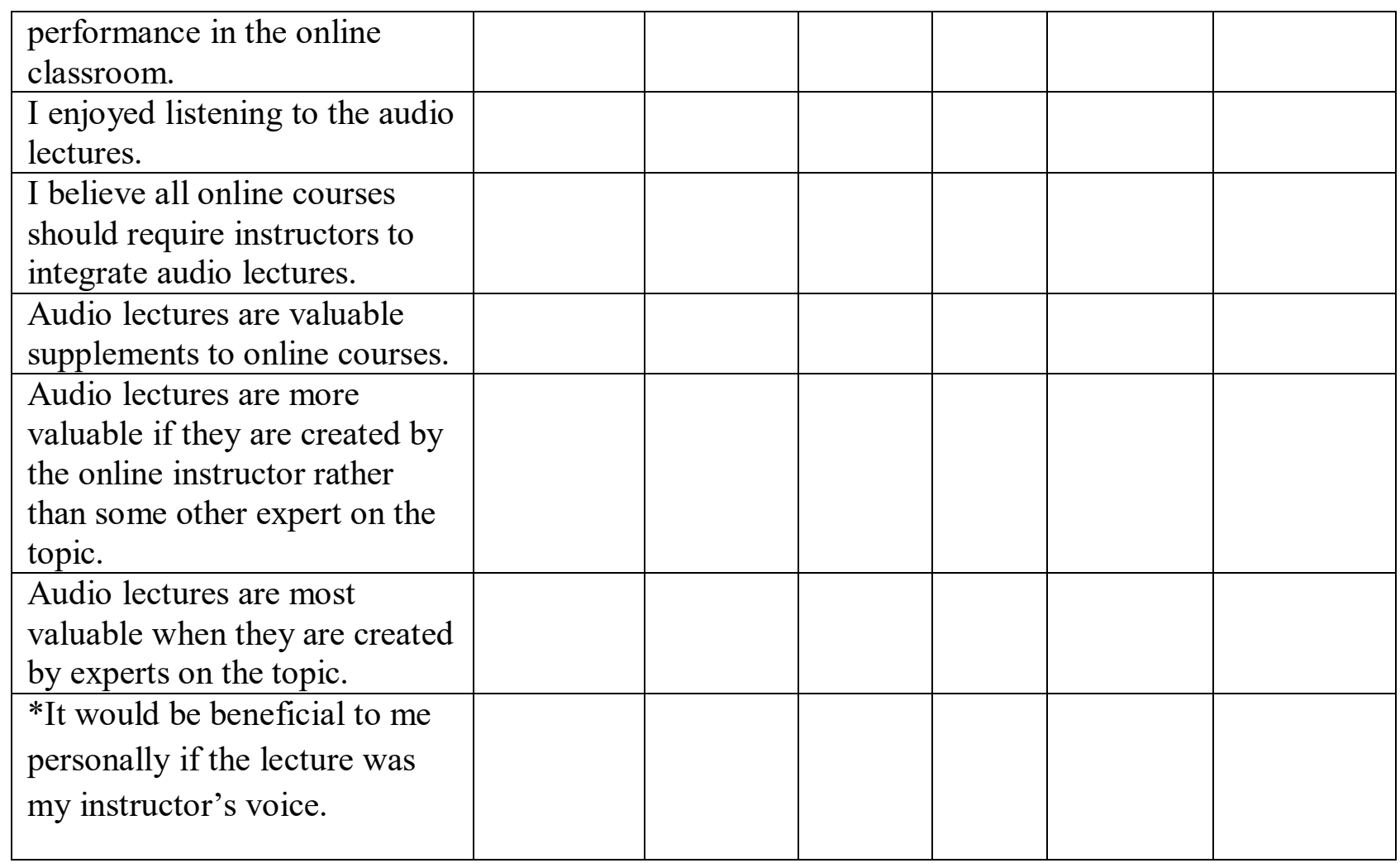

How beneficial was the auditory lecture to you personally? Please explain your answer.

*This question was only asked on the standardized questionnaire.

\section{References}

Berner, E. S., \& Adams, B. (2004). Added value of video compared to audio lectures for distance learning. International Journal Of Medical Informatics, 73(IMIA Working Group on Education), 189-193. https://doi.org/10.1016/j.ijmedinf.2003.12.001

Bickerdike, S., Whittle, S. R., \& Pickering, J. D. (2014). Do lecture audio-recordings support engagement and flexible learning?. Medical Education, 48(5), 522-523. https://doi.org/10.1111/medu. 12442

Bligh, D. A. (2000). What's the Use of Lectures?. San Francisco, CA: Jossey-Bass.

Brown, A., Brown, C., Fine, B., Luterbach, K., Sugar, W., \& Vinciguerra, D.C. (2009). Instructional uses of podcasting in online learning environments: A cooperative inquiry study. Journal Of Educational Technology Systems, 37(4), 351-371. https://doi.org/10.2190/ET.37.4.b

Cheng, C. C., Krumwiede, D., \& Sheu, C. (2009). Online audio group discussions. International Journal Of Market Research, 51(2), 219-241. Retrieved from https://lopes.idm.oclc.org/login?url=http://search.ebscohost.com/login.aspx?direct=true\& $\mathrm{db}=$ edsbl\&AN $=\mathrm{RN} 247047838 \&$ site $=$ eds-live \&scope $=$ site 
Chong Ho, Y., Brewer, L., Angel-Jannasch-Pennell, \& DiGangi, S. (2010). Adopting Web 2.0 for Instruction: The Effects of Faculty Rank and Employment Status. Journal Of Technology Integration In The Classroom, 2(2), 131-143. Retrieved from https://lopes.idm.oclc.org/login?url=http://search.ebscohost.com/login.aspx?direct=true \& $\mathrm{db}=\mathrm{edb} \& \mathrm{AN}=55325099 \&$ site $=$ eds-live \&scope $=$ site

Clark, R. C., \& Mayer, R. E. (2011). E-Learning and the science of instruction: Proven guidelines for consumers and designers of multimedia learning ( $3^{\text {rd }}$ Edition) San Francisco, CA: John Wiley \& Sons.

Copley, J. (2007). Audio and video podcasts of lectures for campus-based students: production and evaluation of student use. Innovations In Education \& Teaching International, 44(4), 387-399. https://doi.org/10.1080/14703290701602805

Cragg, C., Andrusyszyn, M. A., \& Humbert, J. (1999). Experience with Technology and Preferences for Distance Education Delivery Methods in a Nurse Practitioner Program. Journal Of Distance Education, 14(1), 1-13. Retrieved from https://lopes.idm.oclc.org/login?url=http://search.ebscohost.com/login.aspx?direct=true \&

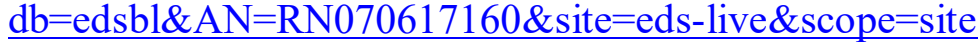

Dammers, R. (2009). Utilising Internet-based videoconferencing for instructional music lessons. Applications of Research in Music Education 28(1), 17-24. Retrieved from https://lopes.idm.oclc.org/login?url=http://search.ebscohost.com/login.aspx?direct=true\& $\mathrm{db}=$ eric\&AN $=\mathrm{EJ} 860034 \&$ site $=$ eds-live \&scope $=$ site

den Brok, P., Levy, J., Brekelmans, M., \& Wubbles, T. (2005). The Effect of Teacher Interpersonal Behaviour on Students' Subject-Specific Motivation. Journal Of Classroom Interaction, 40(2), 20-33. Retrieved from https://lopes.idm.oclc.org/login?url=http://search.ebscohost.com/login.aspx?direct=true\& $\mathrm{db}=$ eric\&AN $=\mathrm{EJ} 768700 \&$ site $=$ eds-live \&scope $=$ site

Dobbins, K. (2011). Reflections on SoTL by a casual lecturer: Personal benefits, long-term challenges. International Journal for the Scholarship of Teaching and Learning, 5(2). Retrieved from http://digitalcommons.georgiasouthern.edu/cgi/viewcontent.cgi?article=1309\&context=ij $\underline{- \text { sotl }}$

Dzakiria, H., Kasim, A., Mohamed, A. H., \& Christopher, A. A. (2013). Effective Learning Interaction as a Prerequisite to Successful Open Distance Learning (ODL): A Case Study of Learners in the Northern State of Kedah and Perlis, Malaysia. Turkish Online Journal Of Distance Education, 14(1), 111-125. Retrieved from https://lopes.idm.oclc.org/login?url=http://search.ebscohost.com/login.aspx?direct=true\&

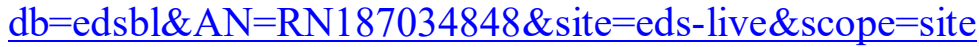

Evering, L. C., \& Moorman, G. (2012). Rethinking plagiarism in the digital age. Journal of Adolescent \& Adult Literacy, 56(1), 35-44. http://dx.doi.org/10.1002/JAAL.00100

Falloon, G. (2011). Making the connection: Moore's Theory of Transactional Distance and its relevance to the use of a virtual classroom in postgraduate online teacher education. Journal of Research On Technology in Education International Society For Technology in Education, 43(3), 187-209. Retrieved from https://lopes.idm.oclc.org/login?url=http://search.ebscohost.com/login.aspx?direct=true\& $\mathrm{db}=$ edsbl\&AN $=\mathrm{RN} 297047382 \&$ site $=$ eds-live \&scope $=$ site

Fernandez, L. (2007). I Upload Audio, Therefore I Teach. Chronicle Of Higher Education, 53(18), B27-B28. Retrieved from 
https://lopes.idm.oclc.org/login?url=http://search.ebscohost.com/login.aspx?direct=true\& $\mathrm{db}=$ eric $\& \mathrm{AN}=\mathrm{EJ} 756226 \&$ site $=$ eds-live $\&$ scope $=$ site

Garrison, D. R., Anderson, T., \& Archer, W. (2000). Critical inquiry in a text-based environment: Computer conferencing in higher education. The Internet and Higher Education, 2(2-3), 87-105. Retrieved http://cde.athabascau.ca/coi_site/documents/Garrison_Anderson_Archer_Critical_Inquiry model.pdf

Hallet, T., \& Faria, G. (2006). Teaching with multimedia: do bells and whistles help students learn? Journal Of Technology In Human Services, 24(2/3), 167-179. Retrieved from https://lopes.idm.oclc.org/login?url=http://search.ebscohost.com/login.aspx?direct=true \& $\mathrm{db}=$ edsbl\&AN $=\mathrm{RN} 194275558 \&$ site $=$ eds-live \&scope $=$ site

Handelsman, M. M., Briggs, W. L., Sullivan, N., \& Towler, A. (2005). A Measure of College Student Course Engagement. The Journal of Educational Research, (3). 184. Retrieved from https://lopes.idm.oclc.org/login?url=http://search.ebscohost.com/login.aspx?direct=true\& $\underline{\mathrm{db}}=$ edsbl\&AN $=\mathrm{RN} 162220698 \&$ site $=$ eds-live\&scope $=$ site

Huerta-Wong, J. E., \& Schoech, R. (2010). Experiential Learning and Learning Environments: The Case of Active Listening Skills. Journal Of Social Work Education, 46(1), 85-101. Retrieved from http://explore.bl.uk/primo_library/libweb/action/display.do?tabs=detailsTab\&gathStatTa $\mathrm{b}=$ true \&ct $=$ display\& $\mathrm{fn}=$ search \&doc $=$ ETOCRN613373549\&ind $\mathrm{x}=1 \&$ recIds $=$ ETOCRN26 $\underline{7145476}$

Kamlaskar, C.H., \& Killedar, M. (2015). Design and delivery of online courses in YCMOU. Turkish Online Journal Of Distance Educaiton (TOJDE), 16(2), 137-150. https://doiorg.lopes.idm.oclc.org/10.17718/tojde.46501

Kaplan-Leiserson, E. (2005). Trend: Podcasting in Academic and Corporate Learning 2005 at http://www.learningcircuits.org/2005/jun2005/0506 trends.htm.

Kaufman, A., \& Dodge, T. (2009). Student perceptions and motivation in the classroom: exploring relatedness and value. Social Psychology Of Education, 12(1), 101-112. https://doi.org/10.1007/s11218-008-9070-2

Kuo, Y., Walker, A. E., Belland, B. R., Schroder, K. E., \& Kuo, Y. (2014). A Case Study of Integrating Interwise: Interaction, Internet Self-Efficacy, and Satisfaction in Synchronous Online Learning Environments. International Review Of Research In Open And Distance Learning, 15(1), 161-181. Retrieved from https://lopes.idm.oclc.org/login?url=http://search.ebscohost.com/login.aspx?direct=true\&

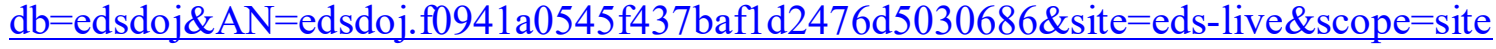

Kurt, A. A. (2011). Personalization principle in multimedia learning: Conversational versus formal style in written word. Turkish Online Journal of Educational Technology 10(3), 185-192. Retrieved from https://lopes.idm.oclc.org/login?url=http://search.ebscohost.com/login.aspx?direct=true\& $\mathrm{db}=$ eric \&AN $=$ EJ944963\&site $=$ eds-live \&scope $=$ site

Leibold, N., \& Schwarz, L. M. (2015). The Art of Giving Online Feedback. Journal Of Effective Teaching, 15(1), 34-46. Retrieved from https://lopes.idm.oclc.org/login?url=http://search.ebscohost.com/login.aspx?direct=true\&

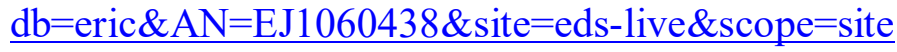


Lister, M. (2014). Trends in the Design of E-Learning and Online Learning. Journal Of Online Learning \& Teaching, 10(4), 671-680.

https://lopes.idm.oclc.org/login?url=http://search.ebscohost.com/login.aspx?direct=true \& $\mathrm{db}=$ ehh\&AN $=100728968 \&$ site $=$ eds-live \&scope $=$ site

Mandernach, B. J. (2009). Effect of instructor-personalized multi-media in the online classroom. Instructional Review of Research in Open and Distance Learning 10(3), 1-19. Retrieved from

https://lopes.idm.oclc.org/login?url=http://search.ebscohost.com/login.aspx?direct=true \& $\mathrm{db}=$ edsdoj\&AN=edsdoj.7460b19125c24c2081405179858a26d1\&site $=$ edslive \&scope $=$ site

Mercer, L., \& Pianosi, B. (2012). Age Matters: Student Experiences with Audio Learning Guides in University-based Continuing Education. Canadian Journal of University Continuing Education, 38(1), 1-11. Retrieved from https://lopes.idm.oclc.org/login?url=http://search.ebscohost.com/login.aspx?direct=true \& $\mathrm{db}=\mathrm{ehh} \& \mathrm{AN}=90537350 \&$ site $=$ eds-live \&scope $=$ site

Moore, M. (1997). Theory of transactional distance. In D. Keegan (Ed.), Theoretical priniciples of distance education (pp.22-38). New York: Routledge.

Mueller, B., Mandernach, B. J., \& Sanderson, K. (2013). Adjunct versus Full-Time Faculty: Comparison of Student Outcomes in the Online Classroom. Journal of Online Teaching and Learning, 9(3). Retrieved from http://jolt.merlot.org/vo19no3/mueller_0913.htm

Murray, M., Pérez, J., Geist, D., Hedrick, A., \& Steinbach, T. (2012). Student Interaction with Online Course Content: Build It and They Might Come. Journal of Information Technology Education, 11, 125-140. Retrieved from https://lopes.idm.oclc.org/login?url=http://search.ebscohost.com/login.aspx?direct=true \& $\mathrm{db}=$ edsdoj\&AN=edsdoj.57d7e105fff24ed2b14ca43fe2cc6d42\&site=eds-live\&scope $=$ site

Ralph, J., \& Olsen, S. (2007). Podcasting as an Educational Building Block in Academic Libraries. Australian Academic \& Research Libraries, 38(4), 270-279. Retrieved from http://explore.bl.uk/primo_library/libweb/action/display.do?tabs=detailsTab\&gathStatTa $\mathrm{b}=$ true \&ct $=$ display\& $\mathrm{fn}=$ search\&doc $=$ ETOCRN613373549\&ind $\mathrm{x}=1 \&$ recIds $=\mathrm{ETOCRN} 22$ 2676482

Spikard III, A., Alreajeh, D., Cordray, J., \& Gigante, J. (2002). Learning about screening using an online or live lecture: does it matter? Journal of General Internal Medicine, 17(7), 540-545. https://doi.org/10.1046/j.1525-1497.2002.10731.x

Spickard III, A., Smithers, J., Cordray, D., Gigante, J., \& Wofford, J.L. (2004). A randomized trial of an online lecture with and without audio. Medical Education 38(7), 787-790. https://doi.org/10.1111/j.1365-2929.2004.01824.x

Stiffler, D., Stoten, S., \& Culle, D. (2011). Podcasting as an instructional supplement to online learning: a pilot study. CIN: Computers, Informatics, Nursing, 29(3), 144-148, https://doi.org/10.1097/NCN.0b013e3181fc3fdf

Wang, C., Shannon, D.M., \& Ross, M.E. (2013). Students' characteristics, self-regulated learning, technology self-efficacy, and course outcomes in online learning. Distance Education 34(3), 302-323. Retrieved from https://lopes.idm.oclc.org/login?url=http://search.ebscohost.com/login.aspx?direct=true \& $\mathrm{db}=$ edsbl\&AN $=\mathrm{RN} 341501724 \&$ site $=$ eds-live \&scope $=$ site.

Wei, F., Chen, G., \& Wang, C. (2007). Ubiquitous Discussion Forum: Introducing Mobile Phones and Voice Discussion into a Web Discussion Forum. Journal of Educational

Journal of the Scholarship of Teaching and Learning, Vol. 18, No. 4, December 2018. 
Multimedia \& Hypermedia, 16(2), 125-140. Retrieved from https://lopes.idm.oclc.org/login?url=http://search.ebscohost.com/login.aspx?direct=true\& $\mathrm{db}=$ edsbl\&AN=RN209390930\&site $=$ eds-live\&scope $=$ site

Williams, J., \& Fardon, M. (2007). Perpetual connectivity: Lecture recordings and portable media players. In ICT: Providing choices for learners and learning. Proceedings ascilite Singapore 2007. Retrieved from http://www.ascilite.org.au/conferences/singapore07/procs/williams-jo.pdf

Witbrock, M.J., \& Haumptmann, A.G. (1997). Using words and phonetic strings for efficient information retrieval from imperfectly transcribed spoken documents. Paper presented at the second ACM International Conference on Digital Libraries, July, 23-26, 1997, Philadelphia, USA. Retrieved from http://lastchance.inf.cs.cmu.edu/alex/d197.pdf 